\title{
FORUM
}

Submitted 07.27.2013. Approved 11.28.2013

This article is co-authored by a member of RAE's Scientific Editorial Board and was evaluated by double blind review process with impartiality and indepedence.

Scientific Editors: Ernesto R. Gantman, Helà Yousfi and Rafael Alcadipani

DOI: http://dx.doi.org/10.1590/So034-759020150203

\section{AN ANTI-MANAGEMENT STATEMENT IN DIALOGUE WITH CRITICAL BRAZILIAN AUTHORS}

\author{
Uma declaração anti-management em diálogo com autores de estudos críticos \\ brasileiros
}

\author{
Una declaración anti-management en diálogo con autores de estudios \\ críticos brasileños
}

\section{MARIA CECI MISOCZKY \\ mcamisoczky@ea.ufrgs.br Professor at Universidade Federal do Rio Grande do Sul, Escola de Administração - Porto Alegre - RS, Brazil}

\section{RAFAEL KRUTER FLORES \\ rafael.flores@ufrgs.br \\ Professor at Universidade Federal do Rio Grande do Sul, Escola de Administração - Porto Alegre - RS, Brazil}

\section{SUELI GOULART}

sueli.goulart@ufrgs.br Professor at Universidade Federal do Rio Grande do Sul, Escola de Administração - Porto Alegre - RS, Brazil

\begin{abstract}
The expressions Management and Organization Studies and Management and Organization Knowledge are expressions of an Anglo-Saxon construct. The association of Organization Studies (OS) with Management (M) produces the subordination of the former to the latter. In a different direction, a critical approach elaborated in Brazilian OS provides an original body of knowledge that expresses an anti-management (A-M) attitude. As the Brazilian A-M authors point out, the distinction between North/South M is irrelevant; what is relevant is a coherent pluriversal A-M attitude. In this paper, we honor and disseminate the Brazilian original body of knowledge on OS and introduce an OS agenda that is liberated from $M$.
\end{abstract}

KEYWORDS | Organization studies, anti-management, organization, social struggles, critique.

\section{RESUMO}

As expressões Estudos Organizacionais e Management e Conhecimento Organizacional e Management são expressões de um construto anglo-saxão. A associação dos Estudos Organizacionais (EOs) com Management produz a subordinação do primeiro ao último. Em outra direção, os EOs críticos brasileiros oferecem um conhecimento original que expressa uma atitude anti-management (A-M). Os autores $A-M$ brasileiros indicam que a distinção entre $M$ do Norte ou do Sul é irrelevante; o que é relevante é uma atitude A-M coerente. Neste artigo, honramos e disseminamos o conhecimento original brasileiro nos EOs e introduzimos uma agenda de EOs liberados do $M$.

PALAVRAS-CHAVE / Estudos organizacionais, anti-management, organização, lutas sociais, crítica.

\section{RESUMEN}

Las expresiones Estudios Organizacionales y Management y Conocimiento Organizacional y Management son expresiones de un constructo anglosajón. La asociación de los Estudios Organizacionales (EOs) con Management produce la subordinación del primero al último. En otra dirección, los EOs críticos brasileños ofrecen un conocimiento original que expresa una actitud anti-management (A-M). Los autores $A-M$ brasileños indican que la distinción entre $M$ del Norte $o$ del Sur es irrelevante; lo que es relevante es una actitud $A-M$ coherente. En este artículo, honramos $y$ diseminamos el conocimiento original brasileño en los EOs e introducimos una agenda de EOs liberados del $M$.

PALABRAS-CLAVE / Estudios organizacionales, anti-management, organización, luchas sociales, crítica. 
The expressions Management and Organization Studies (MOS) and Management and Organization Knowledge (MOK) are themselves expressions of an Anglo-Saxon construct. More than that, the association of Organization Studies (OS) with Management $(M)$ produces, in fact, the subordination of the former to the latter. This subordination has many practical implications: our PhD courses tend to be oriented by the typical managerialist obsession with practice and novelty. Any research that does not contribute to the practice of management is considered outside the field; the study of the organization of social struggles is considered irrelevant; critical management studies (CMS) ends up being an oxymoron - the critical dimension is jeopardized by the impossibility of negating management and contributing to management; among others.

Instead, if we pay attention to the critical Brazilian field of OS, we recognize that the original knowledge produced by a relevant group of authors - Alberto Guerreiro Ramos, Maurício Tragtenberg, Fernando Prestes Motta and, more recently, José Henrique de Faria - expresses an anti-management (A-M) attitude. Therefore, in the Brazilian context, the autonomy of OS from $M$ has historically been the driving force for a creative, autonomous and politically situated knowledge production.

This paper intends to honor this tradition and to discuss its contribution towards the liberation of OS from $M$. This liberation is indispensable for the exercise of plural, decentered and democratic relations organized around projects based on solidarity and pluriversal collectives (Dussel, 2002), instead of singular, centered, subordinated relations organized around projects based on the support of the continually expanding process of capital accumulation.

In the next part we briefly discuss the growing subordination of OS to $M$; following that we review the original contributions of the critical Brazilian authors while focusing on the A-M dimension of their work. Finally, we outline a nonexhaustive agenda for further developments of OS that are liberated from $M$.

\section{THE DOMINANCE OF MANAGEMENT OVER ORGANIZATION STUDIES: A BRIEF REVIEW}

A brief history of $M$ inevitably starts with Taylor and the development of production engineering knowledge (Shenhav, 1999) followed bythe Human Relations Movement, in which the aim is to ensure control over workers in search of efficiency (Wahrlich, 1986), and the construction of the ideology of administrative harmony (Tragtenberg, 1974). Management knowledge (MK) evolved along a path that consisted of incremental changes until the discontinuity introduced by Peter Drucker. According to Ibarra-Colado (2006, p. 464), “[...] chronologically, we first find engineering knowledge, then psychological knowledge and finally MK [...]". This knowledge is constituted of abilities and techniques intended to produce efficacy and efficiency, constant control and performance maximization (Bertero, 2006).

Drucker has been defined as the inventor of $M$ (Byrne, 2005), the father of M (Malik, 2009) or modern M (Starbuck, 2013) or $M$ theory (The Economist, 1994; Ostdick, 2013). For Malik (2009, p. 170), “[...] he laid the foundation for $M$ as a profession of effectiveness [...]. By contrast Tragtenberg (1980a, p. 13) defined his propositions as a “[...] neo-capitalist ideology [...]" that has the "[...] function of legitimating the status quo as the only one possible and desirable [...]". Medina and Misoczky (1997, p. 261) analyzed Drucker's (2002a, 2002b, 2002c) discourse and identified “[...] the reinforcement of knowledge, beliefs and values that contribute to the fatalist naturalization of neoliberal globalization".

For Drucker, $\mathrm{M}$ is neither a science nor an art; it is a practice (Byrne, 2005). He created a theory that despises theory: "What are theories? Nothing. The only thing that matters is how you touch people. Have I given anyone insight? [...] Insight lasts; theories don't”' (Drucker apud Ostdick, 2013, p. 2).

The institutionalization of $M$ as a discipline included the creation of organizations, such as the Academy of Management (AOM), in 1936, which aims to "[...] inspire and enable a better world through our scholarship and teaching about $M$ and organizations" (AOM, 2013). The noun 'organizations' expresses reification; it refers to units of analysis (Cooke, 2004 and 2010; Dar, 2008) that can be separated into “[...] a series of discrete problems that can be solved through the application of technical expertise [...]" (Murphy, 2008, p. 154).

In the European context, the counter-part of the AOM was the European Group of Organization Studies (EGOS, 2013), created in 1973. It institutionalized OS as a discipline that intends to be diverse and plural: "EGOS has its identity and intellectual roots in the social sciences. It encourages an analytical and theoretical approach towards organizations". The aims of EGOS (2013) are: “[...] to further the theoretical and/ or empirical advancement of knowledge about organization, organizing and the context in which organizations operate". The focus and the value attached to theory, the consideration of the verb organize and the attention to the context are wider than those presented by the AOM.

Despite these differences, in recent decades we have witnessed the domination of OS by M. Why is it so? For March 
(2007, p. 10 and 14), EGOS was conceived "[...] as a kind of intellectual social movement within organizations scholarship, defending, developing and extending a particular point of view and producing, augmenting and proclaiming European resistance [...]" to the hegemony of North-American scholars. For him, in the USA, the academic institutionalization of M occurred in the context of postwar economic recovery; while in Europe, the academic institutionalization of OS “[...] occurred in the decades following the protests and counterculture movement of the 1960 s and 1970s". Kelley, Mills, and Cooke (2006) offer a distinct explanation that links academic $M$ in the USA to the Cold War period. Nyland and Heenan (2005) provide evidence that McCarthyism was associated with the eradication of the influence of left-liberal and feminist thinkers. (The influence of the Cold War on how M ideas were imported into Brazil has also been analyzed - see: Alcadipani \& Bertero, 2012).

However, March argues (2007) the resistance to USA (and to $M$ ) hegemony failed, resulting in the creation of the myth of OS as a distinct field. The dominance of OS by $M$ has been exacerbated with the triumph of markets, according to March (2007); or with instruments to restore class dominance within the wider neoliberal project, according to Harvey (2007).

To complete this brief discussion of the dominance of $M$ over OS, which is consolidated in the Anglo-Saxon construct MOS or MOK, we quote Parker (2002, p. 222):

[...] what of $M$ ? Is this a word and associated set of concepts that can also be reimagined and expanded in more emancipatory directions? [...] As it is presently constituted, $M$ is premised on the separation of intellectual and practical labor. It is intimately tied up with a particular professionalization project, with certain ideas about expertise and personhood, as well as the huge legitimation industry associated with the business school, training centers, consultancy firms, and magazine and books publishers and so on. Yet, it is presented as if it were a neutral technology of organizing [...]. It is not a question of who manages, of substituting bad $M$ for good $M$, but a question of the construction of historically particular organizational forms. Organization, in the most general sense of patterning and arranging, is not necessary managerial.

It is also not a question of substituting Northern $M$ for Southern $M$, as seems to be the argument put forward by
Alcadipani, Khan, Gantman \& Nkomo (2012, p. 34): "the studies of MOK portraying the South partly depicted domestic practices as dysfunctional relative to some ideal form of effective and modern M practices from the North". The following review of the Brazilian original A-M will make this reservation clearer.

However, before that, it is necessary to say that, in recent decades, an A-M perspective has been present in most of the academic institutions involved with public administration and business. More than that, this perspective has become, for some of them, a defining feature. What makes the Brazilian critical tradition (Paula, Maranhão, Barreto \& Klechen, 2010) worth mentioning is not any assumption of exclusivity, but its originality and the fact that most of it predates CMS and is contemporary with key foundational works, such as "Labor and Monopoly Capital” (Braverman, 1974).

\section{THE ORIGINAL ANTI-MANAGEMENT BRAZILIAN THOUGHT ON OS}

The fact that this critique of $M$ from the OS point of view existed long before CMS gained relevance in the international scenario enables us to say that the original Brazilian OS was critical from the start. However, as Brazilians, we should recognize that the vast majority of our research and teaching reproduces mainstream international approaches, positioning ourselves as consumers and disseminators of theories and fads from the North, mainly from USA and, more recently, the UK (Wahrlich, 1979; Machado-da-Silva, Cunha, \& Amboni, 1990; Bertero \& Keinert, 1994; Vergara \& Carvalho Jr., 1995; Bertero, Caldas, \& Wood Jr., 1999; Rodrigues \& Carrieri, 2001; Vergara, 2001; Vieira \& Carvalho, 2003; Misoczky, 2006), in an academic context that has also been defined by the domination of OS by $M$.

However, against this background of disciplined subordination, an original, situated and critical tradition emerged and has become central to the configuration of Brazilian OS (Paula et al., 2010). Let us briefly engage with the approaches adopted by these authors, highlighting their A-M position. The purpose is not to provide an extensive review of the many contributions and the inspiration provided by these authors, but to illustrate their critique of $M$ and to establish, in the final part of this paper, a critical-propositional dialogue with them.

The intellectual trajectory of Alberto Guerreiro Ramos (1915-1982) was marked by a constant concern with the production of an original and radically humanist body of knowledge (Azevêdo, 2006) that could contribute towards both providing an understanding of and bringing about changes in the Brazilian reality. Guerreiro Ramos was also an activist of 
the black movement and, for a short period of time, an elected member of the National Congress, losing his mandate as a result of a decree by the military dictators and being forced into exile he went to the USA where he worked and lived for the rest of his life. His intellectual trajectory may be defined as being based on a critical phenomenological perspective (Faria, 2009) and includes two authors who are constantly present in his work: Edmund Husserl and Karl Mannheim. However, as an eclectic erudite author he established dialogues with a wide range of authors, including Max Weber and Erich Fromm.

In the 1950s, Guerreiro Ramos held a number of administrative positions in the Brazilian government and was a founding professor of the Brazilian School of Public Administration. Around that time he produced a major contribution to the conceptualization of the racial problem in Brazil (Guerreiro Ramos, 1954). He also elaborated a key reference for all those interested in breaking with the subaltern reproduction of theories produced in central countries. In the book A Redução Sociológica (Sociological Reduction), first published in 1958, he opposed the “[...] literal and passive assimilation of imported scientific products [...]" and proposed a method of critical assimilation: a process of distilling the international social science literature, so as to reduce it to the part that is relevant, and therefore useful, to peripheral countries (Guerreiro Ramos, 1965, p. 80).

About this time, Guerreiro Ramos became increasingly interested in organizations and public administration. In 1966 he published Administração e contexto brasileiro (Administration and Brazilian context), in which he aimed to outline a 'sociology of administration'. The two paired concepts, instrumental/ substantive rationality and ethics of responsibility/conviction, were central to his objectives. He defined administrative action as a "[...] modality of social action, endowed with instrumental rationality, which assumes that its agents are under the influence of an ethics of responsibility [...]". Therefore, the reason for the administrative action is merely "[...] efficacy, the productive operation of combining resources and means for the achievement of pre-determined contingent objectives" (Guerreiro Ramos, 1983, p. 47-8).

His last book, A nova ciência das organizações, was also published in English by the University of Toronto Press, in 1981, under the title "The new science of organizations: a reconceptualization of the wealth of nations". In this book, Guerreiro Ramos (1989, p. 1) made his A-M argument clearer: "Organization theory as it has prevailed is naïve because it is predicated on the instrumental rationality inherent to the dominant Western social science. In fact, until now, this naïveté has been the fundamental reason for its practical success".
Today, the market tends to become the shaping force of society at large, and the peculiar type of organization that meets its requirements has assumed the character of a paradigm for organizing human existence at large. In such circumstances, the market pattern of thinking and language tends to become equivalent to patterns of thinking and language at large; this is the environment of cognitive politics. Established organizational scholarship is uncritical or unaware of these circumstances, and thus is itself a manifestation of the success of cognitive politics (Guerreiro Ramos, 1989, p. 92).

The concept of cognitive politics was central to his critique of managerialism, being defined as "the conscious or unconscious use of a distorted language with the objective of inducing the people to interpret reality in terms that are convenient for the interest of the direct or indirect agents of this distortion" (Guerreiro Ramos, 1989, pp. 86-87). Organizations are, for him, cognitive systems. Their members internalize the instrumental values, thus becoming unconscious thinkers. At the core of this critique lie the notion of instrumental rationality and the identification of its prevalence in the market system, although it may be in the guise of a normative dimension.

Maurício Tragtenberg (1929-1998) was the founder of critical Brazilian OS (Faria, 2009), producing a coherent line of thought that included the explanation of the relation between the bureaucratic organization and capitalism, as well as the belief in the possibility of defeating them by the selforganization of the dominated. Beyond his theoretical legacy, Tragtenberg provided lessons in activism, participating in the libertarian movements and in the reorganization of the labor movement in the Metalworkers Union Opposition, among others (Morel, 1999). He defined himself as a Marxist anarchist, an "aberration" (Tragtenberg, 2012).

In his PhD thesis Burocracia e Ideologia (Bureaucracy and Ideology), Tragtenberg's main argument is that:

The General Theory of Administration is ideological; it carries in itself the basic ambiguities of the ideological process, which consist in the following: it is connected to the real social determinations as a technique (of industrial, administrative and commercial work) mediated by labor and, at the same time, it moves away from these real social determinations, deforming the real, like an ideology (Tragtenberg, 1974, p. 89). 
For Tragtenberg (1974, p. 209), this ideological dimension “[...] represents the translation of a socio-economic, historically defined praxis in terms of $M$ language". Therefore, the field of $M$ studies is, itself, alienated. He criticized managerialism at the time it was becoming hegemonic: "the constant use of the term $M$ has the objective of concealing conflict and psychological difficulties under the assumption of technically organized relationships" (Tragtenberg, 1980, p. 43). He also criticized the ideological discourse of worker participation, defining it as a means of ensuring a more effective control over and subordination of the labor force. He went further, discussing the role of education in producing disciplined individuals: “[...] the university reproduces the dominant capitalist mode of production; not only by the ideology it conveys, but by the servants it forms [...]" (Tragtenberg, 1990, p. 13).

Tragtenberg (1986, p. 10) dedicated a large part of his work to the theme of self-organization and horizontal social relations. For him, practices such as factory commissions, strike committees and workers councils, provided plenty of possibilities:

What erodes capitalism is the creation of these organizations because they deny the verticality of the existing organizations, be it the state, the party, or the union. As a consequence of direct action by workers, they lose their finality of controlling the working force. With the mediation of institutions created in the socio-political process, the working class self-manages its struggles and, therefore, decision making and execution are in the workers' hands.

Based on the analysis of the Soviet 'socialism', defined as bureaucratic state capitalism, as well as the consideration of historical working struggles, Tragtenberg $(1986,1988)$ arrived at a definition of socialism as something that cannot be separated from the self-organization of those who struggle for their liberation.

In the words of Faria (2009, p. 514), Tragtenberg's work can be defined

[...] by the refusal of any form of domination, the critique of violence, the denouncement of bureaucratization, the argument that the so-called general theory of administration is the expression of a managerialist ideology, and the intransigent defense of democracy and the libertarian project.

Another Brazilian A-M author was Fernando Prestes Motta (1945-2003), an original and eclectic intellectual who was influenced by and established dialogues with many authors, including Weber, Marx, Althusser, Poulantzas, Foucault, Freud, Enriquez, and Dejours, among others.

In his MSc dissertation, Prestes Motta (1969) analyzed capitalist rationalism and the evolution of Brazilian enterprises. In his PhD thesis, he opposed bureaucracy to self-management in his discussion of Proudhon's proposals (Prestes Motta, 1981). Before that, in 1972, Prestes Motta had published his first book - Teoria Geral da Administração: uma introdução (General Theory of Administration: an introduction), in which he not only reviewed the theory (from Taylor to the Aston Group), but also provided a critical analysis of its function. He further developed this idea in another book - Teoria das Organizações: evolução e crítica (Organizational Theory: evolution and critique), first published in 1986. In his words:

As a field of instrumental knowledge as well as a world vision, OT reflects the growing power of the technobureaucratic elite in the countries of monopolist state capitalism. [...] The purpose of this book is to give, initially, an overview of organizational and administrative theory, establishing its main steps, followed by its analysis as an ideology of power (Prestes Motta, 2001a, p. v).

Power was the central issue for him, be it in relation to bureaucracy, ideology, $M$, culture or psychoanalysis. According to Prestes Motta (2001b), he was influenced by Tragtenberg, mainly in Organização e poder: empresa, Estado e escola (Organization and power: enterprise, state and school). The book's central argument presents the techno-bureaucracy as a social class constitutive of capitalism, a class that lives for the reproduction and extension of its own power and sustains a form of organization that is constantly changing as a consequence of the general conditions of production and $M$. As a complement, mainstream OT is the ideological expression of the practices of that social class and the school is the space where both the strategy of reproduction and the naturalization of domination are produced (Prestes Motta, 1986).

Convinced that the "[...] fundamental characteristic of bureaucratic administration is hetero-management and that the only radical alternative is self-management [...]", Prestes Motta (1981, p. 10) discussed Proudhon's propositions. Self-management would be an organizational practice that $t$ respects freedom and pluralism, a possibility of government by the masses that disturbs the powerful, negates bureaucracy and “[...] brings uncertainty to a world where everyone looks for certainties [...]": "[...] while the ideologies of power try to hide the multiple alienations of the modern man, the proposal of self-management can be seen as a denouncement, and as the real and radical possibility of social transformation" (Prestes Motta, 1981, p. 166-7). 
José Henrique de Faria has also critically analyzed power relations in organizations. In 2001, he proposed a specific field of studies: the political economy of power in OS. Adopting references from the Frankfurt School's first generation in association with Marxist theories about state, class and power and theories from the fields of critical psycho-sociology and Freudian psychoanalysis, Faria (2004a, p. 19) defines his aim as the production of a "[...] genetic epistemology of control in organizations under the command of capital [...]", including objective and subjective dimensions.

In search of the theoretical foundations of these forms of control, he identifies the "[...] ideology of capitalist $M$, also known as managerialist theory": "[...] a system of ideas that both reproduces the logic of capital's domination over labor and offers 'scientific' support to legitimate the actions derived from such a logic". He draws on a set of empirical studies of productive organizations to analyze the construction and enhancement of systems of control in order to make them less visible and more efficient: “[...] capitalist $M$, by means of its techniques, not only emphasizes the separation between intellectual and manual work, it also looks to increase the capacity of managers to command and demand obedience from workers" (Faria, 2004b, p. 152). $M$ is a theory of power: "[...] a discourse of capital's control over work and workers [...]"; it is not related "[...] to the history of scientific thought [...]", it is related to "[...] the history of capitalism" (Faria, 2004b, pp. 156-157).

In his work, Faria (2004b) provides a consistent critique of $M$. At the same time, he recognizes the existence of alternatives produced by social movements that promote self-management and oppose the autocratic nature of $M$. However, these initiatives cannot be considered within the limits of $M$ theory, precisely because they challenge the capitalist productive structure and the political regime of the present capitalist state.

A defining feature of the authors revised above is their A-M attitude. They have produced an original body of knowledge, showing us that it is possible to work in Management and Administration Departments within academic institutions without subordinating our practice to the hegemony of $M$, and provided endless inspiration for many of us. Their relevance and the growing number of people interested in their work can be seen, for example, in recent events such as the special issue of the journal "Organização \& Sociedade” (Revista Organizações \& Sociedade, 2010) dedicated to Guerreiro Ramos; the special issue dedicated to Tragtenberg in the journal "Espaço Acadêmico" (Revista Espaço Acadêmico, 2013); and the International Colloquium of OS organized in 2014 by the Fundação Getulio Vargas, that dedicated part of the program to Prestes Motta.
For reasons of space, we have to close this brief and selective review here. We do not think that a coherent pattern of critique can be traced to articulate the works of these authors. Each of them had their own political and epistemological position, each of them chose to address specific topics, and each of them constructed a personal trajectory within their particular contexts. What can be said is that they provide, regardless of each one's specificity, fertile ground for those interested in making a truly critical assessment of $M$ and, therefore, in the emancipation of OS from $M$.

In the first part of this essay, we stated that we saw no relevance in substituting Northern $M$ for Southern $M$. We hope that, by highlighting the ideas provided by these authors, the grounds for maintaining that attitude have become clearer. MK was born within the market and for the market, its mainstream and even some self-portrayed critical positions have at their origin and as their raison d'être the improvement of tools for ensuring control over living labor that are indispensable for the reproduction of a system that aims to control all spheres of life.

With regard to our personal academic lives, we can also learn an important lesson from these authors: it is possible to live a fruitful coherent A-M intellectual life without subordinating oneself or compromising the situated political position. In such a way, we can avoid the practice defined by Tragtenberg (1990) as "academic delinquency".

\section{THE LIBERATION OF ORGANIZATION STUDIES FROM MANAGEMENT: OPEN POSSIBILITIES}

In accordance with the intellectual tradition reviewed above, the reflection that follows is related to the possibilities of producing counter-hegemonic knowledge in an academic space still dominated by MK and, worst, by its current managerialist expression as an "[...] ideology of control, progress and order is produced and reproduced [...]” (Dar, 2008, p. 95).

We believe that there is an indispensable need to consolidate a field of OS that is liberated from $\mathrm{M}$, a field that is necessary at least for those intending to adopt a critical approach, as the above-mentioned authors taught. However, while they should be honored for their commitment, authenticity and engagement with the issues and events of their time, their critiques and propositions should not be taken as sacred. Coherently, the best way to honor them is to recognize their limitations and to continue pushing along the paths they opened. In the following paragraphs, we will outline a propositional, 
although not exhaustive agenda for the further develop and consolidation of a Brazilian OS that is liberated from $\mathrm{M}$.

The first aspect to consider is that the last three authors reviewed above provided two moments of critique: the negative denouncement and the positive announcement of the construction of the new. However, when announcing the new, they ended up being caught in the pervasive managerial web. Self-management has been taken for granted as the praxis that would confront and subvert the system. This proposition is understandable if we consider that Tragtenberg and Prestes Motta were writing in the years following the events of May 1968:

The fact is that the effervescence and strength of the events of May 1968 in France transformed the expression self-management from a specific concept that originated in the context of Yugoslavian state capitalism into the status of a magic word that expresses, simultaneously, a utopian image and a means for liberation, despite the intense polysemy that authorizes its use by those who adopt a revolutionary perspective as well as by those who work within a conciliatory reformist perspective such as the so-called solidarity economy (Misoczky \& Moraes, 2011, p. 70).

Here, we are not rejecting the concept of self-management. Instead, we are refusing to take it for granted so as to avoid the risk of inadequately transposing concepts, a practice severely criticized by Guerreiro Ramos (1965). Misoczky and Moraes (2011) warn that, from an extreme perspective, the expression self-management is an oxymoron because $M$ can only be hetero-management. For Avron (1980, p. 3), the expression is inappropriate: "the notion of $\mathrm{M}$ carries an evident connection with economic instrumental rationality". It is reasonable to assume that the idea of self-managing society (Bernardo, 2005) represents the success of managerialism in invading unsuspicious territories, such as those of people who decisively oppose the system of capital. Therefore, the need to avoid the fetishism of the organizational format and to include this theme into an agenda of OS liberated from $\mathrm{M}$.

A second central theme is the organization of social struggles. To widen the ways in which we study organization requires the abandonment of restrictive understandings of it as units of analysis. Misoczky (2010), for example, defines organization as the collective inter-subjective act that is a means for the praxis of liberation and a learning space for the experimentation of liberating organizational practices.
To avoid the naturalization of self-management as a ready-to-use tool when we focus on the organization of social struggles, it is necessary to address a wide set of dimensions. One of these refers to the principle of feasibility, included by Dussel (2004) among the principles of his ethics of liberation, which is the necessary organizational praxis which comes from consciousness and the consequent need for critical intervention to produce change. This is the moment that Dussel (2004, p. 353) calls 'critical-instrumental reason'. For him, the instrumental-strategic reason has a place in the ethical praxis of liberation: "[...] we cannot fall into fetishisms; we cannot ignore the subaltern function of instrumental reason". The problem arises when the feasibility criterion becomes an absolute principle. Dussel (2004, p. 353) provides a description of the principle of ethical feasibility:

An action, an institutional or systemic norm, is ethically operational and concretely feasible if it complies (a) with the conditions of logic, empirical, technical, economic etc., possibilities which are judged by the following (b) [deontic] requirements: (b.1) ethical-material practical truth, and (b.2) formal-moral validity; within a range that goes from (b.a) actions ethically allowed (which are merely possible because they do not contradict ethical and moral principles), until (b.b) mandatory actions, which are 'necessary' for the actualization of basic human needs (materially - the reproduction and development of life; formally - the participation of those affected in decision making).

This principle is ethical because it defines as necessary that all human action that intends to be human and feasible have a dutiful bond with the life of each subject. At the same time, it ensures the recognition of each subject as equal and free. In this process of recognition, however, it is also necessary to organize the praxis of liberation, taking into consideration the natural-physical and technical possibilities available at any historical moment. This is a third theme for an agenda of OS liberated from M: to consider Dussel's formulation in a critical dialogue with Guerreiro Ramos' dismissal of instrumental rationality.

The fourth theme in this indicative agenda is in consonance with Jones and Böhm's (2002) proposition of a general economy of organization, which would be interested in seeing organization as a basic social process. Going further, we propose a political economy of organization that incorporates 
value in the Marxist sense as a key concept: the production of value produces specific forms or organization related to different moments of social life, which can be and are imagined and organized differently by a variety of different groups. Such view of organization is hence deeply political.

To finish we summarize the contributions we have intended to provide: (1) from a critical position, the distinction between Northern/Southern $M$ is irrelevant, what is relevant is a coherent pluriversal A-M attitude; (2) the critical Brazilian OS tradition had already made this previous statement blatantly clear; (3) we have a critical original OS body of knowledge to honor, disseminate and further develop considering the needs of our historical time; (4) the outlined agenda for an OS liberated from M was inspired by Brazilian authors but is intended to be relevant for all those, without distinction between North/South, who conceive their work as critical interventions in conjunction with those engaged in liberating struggles.

\section{REFERENCES}

Alcadipani, R., Khan, F. R., Gantman, E., Nkomo, S. (2012). Southern voices in management and organization knowledge. Organization, 19(2), 131-143.

Alcadipani, R. \& Bertero, O. (2012). Guerra Fria e o ensino do Management no Brasil: o caso da FGV-EASP. RAE-Revista de Administração de Empresas, 52(3), 284-299.

Aom - American Academy Of Management. (2014). Vision, Mission, Objectives \& Values. Retrieved on 12 June, 2013 from http://aom.org/ About-AOM/Vision,-Mission,-Objectives---Values.aspx.

Avron, H. (1980). L'autogestión. Paris: PUF.

Azevêdo, A. (2006). A sociologia antropocêntrica de Alberto Guerreiro Ramos. Tese de Doutorado - Programa de Pós-Graduação em Sociologia Política da UFSC.

Bernardo, J. (2005). A autogestão da sociedade prepara-se na autogestão das lutas. Retrieved on 2 February, 2012 from http://grupogetrama. blogspot.com.br/2009/02/auto-gestao-da-sociedade-prepara-se-na.html.

Bertero, C. O. (2006). Ensino e pesquisa em Administração. Mazon: Thomson.

Bertero, C. O. \& Keinert, T. M. (1994). A evolução da análise organizacional no Brasil (1961-93). RAE-Revista de Administração de Empresas, 34(3), 81-90.

Bertero, C. O., Caldas, M., \& Wood, T. (1999). Produção científica em administração de empresas: provocações, insinuações e contribuições para um debate local. RAE-Revista de Administração Contemporânea, 3(1), 147-178.

Braverman, H. (1974). Labour and monopoly capital: the degradation of work in the twentieth century. New York: Monthy Review Press.

Byrne, J. A. (2005). The man who invented management. Retrieved on 12 June, 2013 from http://www.businessweek.com/stories/2005-11-27/ the-man-who-invented-management.
Cooke, B. (2004). The managing of the (Third) World. Organization, 11(5), 603-629.

Cooke, B. (2010). Managerialism as knowing and making in Latin America: International development management and the World Bank interventions. In: Guedes, A., Faria, A. (Eds) International Management and International Relations: A critical Perspective from Latin America. London: Routledge, pp. 161-184.

Dar, S. (2008). Re-connecting histories: modernity, managerialism and development. Journal of Health Organization and Management, 22(2), 93-110.

Drucker, P. (2002a). O melhor de Peter Drucker: a sociedade. São Paulo: Nobel.

Drucker, P. (2002b). O melhor de Peter Drucker: o indivíduo. São Paulo: Nobel.

Drucker, P. (2002c). O melhor de Peter Drucker: a administração. São Paulo: Nobel.

Dussel, E. (2002). Ética da libertação na idade da globalização. Petrópolis: Vozes.

Dussel, E. (2004). Hacia una Arquitectónica de la Ética de la Liberación. In: Apel, K.-O. \& Dussel, E. (Eds) Ética del discurso y ética de la liberación Madrid: Trotta. pp. 339-366.

Egos. (2012). European Group of Organization Studies. About EGOS. Retrieved on 12 June, 2013 from http://www.egosnet.org/egos/about_egos.

Faria, J. H. (2004a). Economia política do poder: fundamentos. Vol. I. Curitiba: Juruá.

Faria, J. H. (2004b). Economia política do poder: as práticas do controle nas organizações. Vol. III. Curitiba: Juruá.

Faria, J. H. (2009). Teoria crítica em estudos organizacionais no Brasil: 0 estado da arte. Cadernos EBAPE.BR, 7(3), 509-515.

Guerreiro Ramos, A. (1954). Cartilha brasileira do aprendiz de sociólogo. Rio de Janeiro: Editorial Andes.

Guerreiro Ramos, A. (1965). A Redução sociológica. Rio de Janeiro: Tempo Brasileiro.

Guerreiro Ramos, A. (1983). Administração e contexto brasileiro. 2ª . Ed. Rio de Janeiro, FGV.

Guerreiro Ramos, A. (1984). The new science of organizations: reconceptualization of the wealth of nations. Toronto: University of Toronto Press.

Guerreiro Ramos, A. (1989). A Nova ciência das organizações: uma reconceituação da riqueza das nações. $2^{\underline{a}}$ ed. Rio de Janeiro: FGV.

Harvey, D. (2007). Neoliberalism as creative destruction. Annals of the American Academy of Political and Social Science, 610(1), 22-44.

Ibarra-Colado, E. (2006). Organization Studies and epistemic coloniality in Latin America: thinking otherness from the margins. Organization, 13(4), 463-488.

Jones, C. \& Böhm, S. (2002). Hors d'oevre. Ephemera, 2(4), 277-280.

Kelley, E. S., Mills, A. J., \& Cooke, B. (2006). Management as a Cold War phenomenon? Human Relations, 59(5), 603-610.

Malik, F. (2009). 100 years of Peter Drucker. Retrieved on 12 June, 2013 from https://www.malik-management.com/en/pdf/ml/malik-letterenglish-100-years-of-peter-drucker-11-2009.pdf.

Machado-da-Silva, C., Cunha, V. C., \& Amboni, N. (1990). Organizações: o estado da arte da produção acadêmica no Brasil. Anais do XIV ENANPAD, 6, 11-28. 
March, J. G. (2007). The study of organizations and organizing since 1945. Organization, 28(1), 9-19.

Medina, I. P. \& Misoczky, M. C. (2007). Peter Drucker e a legitimação do capitalismo tardio: uma análise crítica de discurso. GESTÃO.ORG, 5(3), 260-283.

Misoczky, M. C. (2006). Sobre o centro, a crítica e a busca da liberdade na práxis acadêmica. Cadernos EBAPE.BR, 4(3), 1-13.

Misoczky, M. C. (2010). Das práticas não-gerenciais de organizar à organização para a práxis da libertação. In: Misoczky, M. C., Flores, R. K., \& Moraes, J. (Orgs) Organização e práxis libertadora. Porto Alegre: Dacasa, 2010. pp. 13-56.

Misoczky, M. C. \& Moraes, J. (2011). Práticas organizacionais em escolas de movimentos sociais. Porto Alegre: Dacasa.

Morel, J. C. O. Maurício Tragtenberg, a solidariedade de classe e as lutas sociais em São Paulo. In: Accioly e Silva, D; Marrach, S. A. (Orgs.) Maurício Tragtenberg: uma vida para as ciências sociais. São Paulo: UNESP, 1999. p. 257-288.

Murphy, J. (2008). The World Bank and global managerialism. London: Routledge.

Nyland, C. \& Heenan, T. (2005). Mary van Kllek, Taylorism and the control of management knowledge. Management Decision, 43(10), 1358-1374.

Ostdick, H. (2010). Peter Drucker: the father of management. Retrieved on 12 June, 2013 from http://www.success.com/articles/1115-peter-drucker-the-father-of-management-theory.

Parker, M. (2002). Utopia and the organizational imagination: eutopia. In: Parker, M. (Ed) Utopia and organization. Oxford: Blackwell, pp. 217-224.

Paula, A. P. P. Maranhão, C. M S. de A.; Barreto, R. de O.; Klechen, C. F (2010). A tradição e a autonomia dos estudos organizacionais críticos no Brasil. RAE-Revista de Administração de Empresas, 50(1), 10-23.

Prestes Motta, F. C. (1972). Teoria Geral da Administração: uma introdução. São Paulo: Pioneira.

Prestes Motta, F. C. (1986). Organização e poder: empresa, Estado e escola. São Paulo: Atlas.

Prestes Motta, F. C. (2001a). Teoria das organizações: evolução e crítica. $2^{a}$. Ed. São Paulo: Pioneira Thomson Learning.

Prestes Motta, F. C. (2001b). Maurício Tragtenberg: desvendando ideologias. RAE-Revista de Administração de Empresas, 41(2), 64-68.

Revista Organizações \& Sociedade. (2010). Salvador: UFBA, 17(52). Edição Especial: Alberto Guerreiro Ramos. Retrieved on 13 November 2013 from http://www2.revistaoes.ufba.br//viewissue.php?id=54.
Revista Espaço Acadêmico. Maringá: UEM, n. 150, November 2013. Dossiê: Atualidade do pensamento de Maurício Tragtenberg. Retrieved on 13 January 2015, from http://www.periodicos.uem.br/ojs/index.php/ EspacoAcademico/issue/current.

Rodrigues, S. B. \& Carrieri, A. P. (2001). A tradição anglo-saxônica nos estudos organizacionais brasileiros. RAC-Revista de Administração Contemporânea, edição especial, 81-102.

Shenhav, Y. (1999). Manufacturing rationality: the engineering foundations of the managerial revolution. Oxford: Oxford University Press.

Starbuck, P. (2013). Peter Drucker: the father of modern management. Retrieved on 12 June, 2013 from http://www.mbsportal.bl.uk/taster/ subjareas/busmanhist/mgmtthinkers/druckerprofile.asp.

The Economist. (1994). Peter Drucker, salvationist. Retrieved on 12 June, 2013 from http://www.economist.com/node/14897396.

Tragtenberg, B. \& Ferraz, D. (2013). Maurício, por Beatriz Tragtenberg. Revista Espaço Acadêmico. Dossiê Atualidade do pensamento de Maurício Tragtenberg, n. 150, ano XIII. Nov., 2013. Retrieved on November 13, 2013 from http://periodicos.uem.br/ojs/index.php/EspacoAcademico/article/view/22378/11897.

Tragtenberg, M. (1974). Burocracia e ideologia. São Paulo: Ática.

Tragtenberg, M. (1980). Administração, poder e Ideologia. São Paulo: Moraes.

Tragtenberg, M. (1986). Reflexões sobre o Socialismo. São Paulo: Moderna.

Tragtenberg, M. (1988). A Revolução Russa. São Paulo: Ática.

Tragtenberg, M. (1990). Sobre Educação, Política e Sindicalismo. São Paulo: Cortez.

Vergara, S. (2001). A hegemonia americana em estudos organizacionais. RAP-Revista de Administração Pública, 35(2), 63-77.

Vergara, S. \& Carvalho Jr. D. S. (1995). Nacionalidade dos autores referenciados na literatura brasileira sobre organizações. Anais do XIX ENANPAD.

Vieira, M. M. F. \& Carvalho, C. A. (2003). Tréplica ao professor Bertero. Organização \& Sociedade, 10(27), 179-180.

Wahrlich, B. S. (1979). Evolução das ciências administrativas na América Latina. RAP-Revista de Administração Pública, 13(1), 31-68.

Wahrlich , B. S. (1986). Uma análise da teoria das organizações. Rio de Janeiro: FGV. 